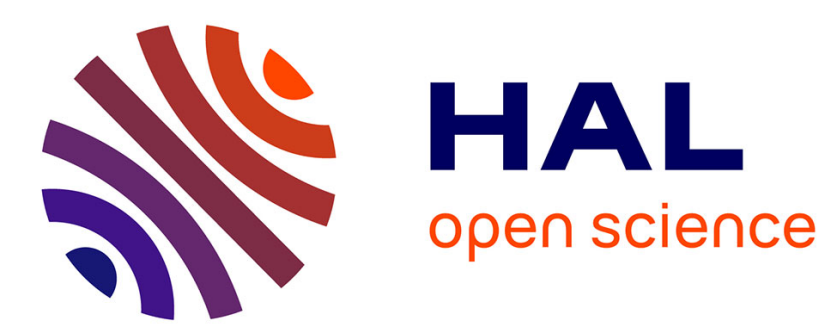

\title{
Seismic properties of gabbroic sections in oceanic core complexes: constraints from seafloor drilling
}

Donna Blackman, Natsue Abe, Richard Carlson, Gilles Guérin, Benoit Ildefonse, Amber Kumpf

\section{- To cite this version:}

Donna Blackman, Natsue Abe, Richard Carlson, Gilles Guérin, Benoit Ildefonse, et al.. Seismic properties of gabbroic sections in oceanic core complexes: constraints from seafloor drilling. Marine Geophysical Research, 2019, 40 (4), pp.557-569. 10.1007/s11001-019-09385-7 . hal-02130206

\section{HAL Id: hal-02130206 \\ https://hal.umontpellier.fr/hal-02130206}

Submitted on 8 Jul 2020

HAL is a multi-disciplinary open access archive for the deposit and dissemination of scientific research documents, whether they are published or not. The documents may come from teaching and research institutions in France or abroad, or from public or private research centers.
L'archive ouverte pluridisciplinaire HAL, est destinée au dépôt et à la diffusion de documents scientifiques de niveau recherche, publiés ou non, émanant des établissements d'enseignement et de recherche français ou étrangers, des laboratoires publics ou privés. 


\section{Query Details}

1. Affiliations: Journal instruction requires a city and country for affiliations; however, these are missing in affiliation $1,2,3,4,5,6$. Please verify if the provided city and country are correct and amend if necessary.

city and country were provided for each co-author and all are correct

2. References (Minshull et al 1991, Morris et al 1999, Purdy and Detrick 1986) were provided in the reference list; however, this were not mentioned or cited in the manuscript. As a rule, if a citation is present in the text, then it should be present in the list. Please provide the location of where to insert the reference citation in the main body text.

These references are all cited in the legend shown in Figure $7 \mathrm{~b}$

\section{Seismic properties of gabbroic sections in oceanic core complexes: constraints from seafloor drilling}

Donna K. Blackman, $1 \otimes$

Phone 760-420-7845

Emaildblackman@ucsd.edu

Natsue Abe, 2

Richard L. Carlson, 3

Gilles Guerin, 4

Benoit Ildefonse, 5

Amber Kumpf, 6 
1 Scripps Institution of Oceanography, University of California San Diego, San Diego, CA, USA

2 Center for Ocean Drilling

Science, JAMSTEC, Yokosuka, Kanagawa, Japan

3 Dept. Geology \& Geophysics, Texas A\&M University, College Station, TX, USA

4 Lamont Doherty Earth Observatory, Columbia University, New York, NY, USA

5 Geosciences Montpellier, CNRS, University of Montpellier, Université des Antilles, Montpellier, France

6 Muskegon Community College, Muskegon, MI, USA

Received: 21 September 2018 / Accepted: 17 April 2019

\section{Abstract}

The physical properties of rock within Oceanic Core Complexes (OCC) provide information about the history of magmatism, deformation and alteration associated with detachment faulting and unroofing of their gabbroic sequences. New core and logging data from Atlantis Bank (AB) OCC are compared with prior deep sea drilling data from this site on the Southwest Indian Ridge, as well as from Atlantis Massif (MFAM) OCC on the Mid-Atlantic Ridge. The average seismic velocity at each site is typical for gabbroic rock. Downhole core and log variations are found to depend on both porosity and alteration. Porosity at millimeter to meter scale impacts P-wave velocities $(6.0-6.4 \mathrm{~km} / \mathrm{s})$ in the upper several hundred meters at both OCC. Below $\sim 600-800 \mathrm{~m}$ depth, in situ velocities are higher $(6.6-6.9 \mathrm{~km} / \mathrm{s})$ for the remainder of the $1.5 \mathrm{~km}$ drilled to date, except in zones where alteration is significant. Variability 
of $0.5-1 \mathrm{~km} / \mathrm{s}$ over depth intervals of a few meters is persistent where mineral alteration exceeds $10-20 \%$, whereas variability drops to \pm $0.1 \mathrm{~km} / \mathrm{s}$ for intervals affected by little to no alteration. Seismic anisotropy is negligible overall, with just a few intervals showing consistent fast azimuth and magnitude of a few percent. The depth extent of alteration, probably related to the zone deformed below the detachment when active, is $\sim 600-800$ meters at both $\mathrm{AB}$ and AM.

\section{Keywords}

Oceanic core complex

Seismic properties of ocean crust

International Oecean Detiscovery Pprogram

JOIDES Rresolution Eexpeditions 304, 305, 340T, and 360

Electronic supplementary material

The online version of this article (https://doi.org/10.1007

/s11001-019-09385-7) contains supplementary material, which is available to authorized users.

\section{Introduction}

Deep sea drilling provides unique access to ocean crustal properties at a scale that allows geologic processes to be addressed. The intrusive portion of the oceanic crust is typically inaccessible at the seafloor so seismic imaging and velocity analysis are applied to infer geologic structure of the basement. Averaging that is inherent in seismic survey methods means that narrow intervals marking key aspects of the geologic evolution of the crust may not be recognized. Here we take advantage of drilling and borehole logging results at two oceanic core complexes (OCCs) to illustrate inherent physical properties and to assess what the downhole variability might indicate about how they formed and the extent to which seismic surveys can and cannot detect such evidence of interplay between magmatism, 
faulting, and fluid circulation.

OCCs expose intrusive crustal sections at/near the seafloor through sustained slip along detachment fault(s), which can be active for periods on the order of $10^{6}$ year within the axial zone of slow spreading centers (e.g., Dick et al. 1991; Cann et al. 1997; Tucholke et al. 1998; Blackman et al. 2002; Escartin et al. 2008; Escartín et al. 2017; Macleod et al. 2009; John and Cheadle 2010). Understanding the inherent physical properties of the unroofed domal 'core' of these complexes can elucidate the footwall evolution during/following fault activity and illuminate aspects of the magmatic accretion that built the section that is penetrated by deep sea drilling.

AQ1

Two OCCs have been targeted for deep penetration by the Ocean Drilling Program (ODP, Legs 118, 176, 179), the Integrated Ocean Drilling Program (IODP Phase 1, Expeditions 304, 305, and 340T) and the International Ocean Discovery Program (IODP Phase 2, Expeditions 360 and 362T). Logging and selected shipboard description/measurement data for these deep penetrations are the main focus of this paper. ODP Hole 735B (Dick et al. 2000) and IODP Hole U1473A (MacLeod et al. 2017) were drilled into the footwall exposed at Atlantis Bank (AB), on the flank of the Southwest Indian Ridge (SWIR); IODP Hole U1309D (Blackman et al. 2011) was drilled into the Central Dome of Atlantis Massif (AM), on the flank of the Mid-Atlantic Ridge (MAR). AB developed as new crust accreted $11 \mathrm{Ma}$ and the OCC subsequently rafted off axis to its current position $\sim 80 \mathrm{~km}$ from the spreading center (Dick et al. 1991). AM developed 1-2 Ma and the east slope of its Southern Ridge currently forms the western rift valley wall near the ridge-transform intersection (Cann et al. 1997; Blackman et al. 2002). Regional seafloor morphology shows that detachment faulting and core complex formation in these areas is an episodic process (Fig. 1), with more typical faulting/magmatism developing linear abyssal hills in the intervening periods. At AB, transtension across the transform also contributed to the high-relief 
morphology (Dick et al. 1991). Half spreading rate in these sections of the SWIR and MAR average $8 \mathrm{~km} /$ Myr (Dick et al. 1991; Hosford et al. 2003) and $12 \mathrm{~km} / \mathrm{Myr}$ (Zervas et al. 1995), respectively.

\section{Fig. 1}

Ridge-transform areas where the $\mathrm{AB}$ (left) and $\mathrm{AM}$ (right), oceanic core complex occur, at the same scale. Brackets on AM map mark the Southern Ridge to the south of the Central Dome). Circles show location of drill holes and Site numbers for which core/log data are discussed. Gray arrows indicate relative plate motion at spreading axes (opposing arrows) and transform faults (single side arrow). Index map also shows locations $(+)$ of Kane core complex (Atlantic) and Hess Deep tectonic window (Pacific) where gabbroic sequences were also recovered 


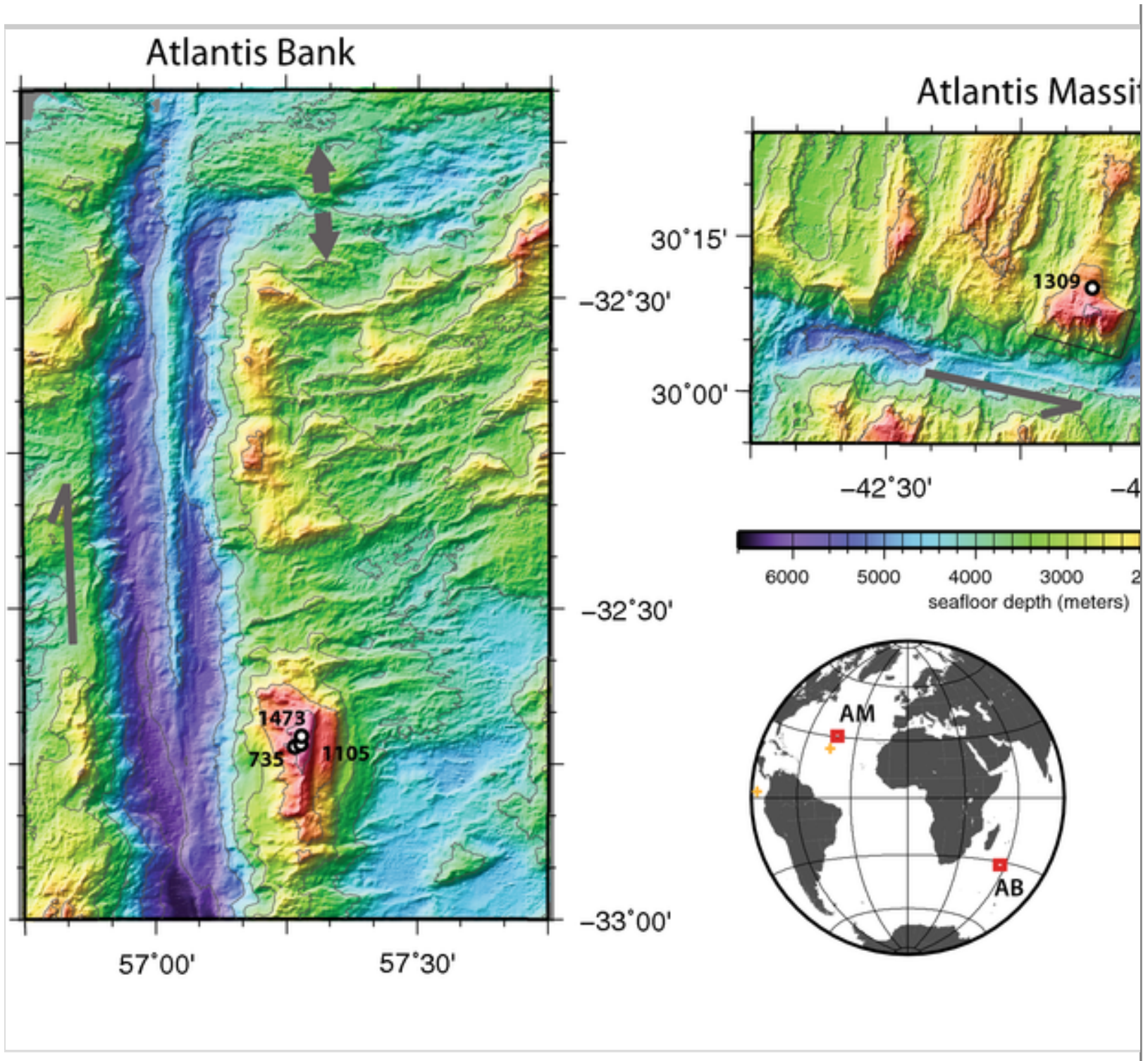

Overall, core recovery from the OCCs was very good (Dick et al. 2000; Blackman et al. 2011; MacLeod et al. 2017) and logging produced a considerable amount of useful data for assessing physical properties. Hole $735 \mathrm{~B}$ at $\mathrm{AB}$ extends $1508 \mathrm{~m}$ below the seafloor and the upper $500 \mathrm{~m}$ was logged during ODP Leg 118 (Robinson and von Herzen 1989). A suite of gabbroic rocks was recovered, with olivine gabbro dominant, intervals of oxide gabbros, and minor troctolite and diabase (Dick et al. 2000). Hole U1473A, $2.2 \mathrm{~km}$ NNE of Hole 735B, penetrated $808 \mathrm{~m}$ through a similar gabbroic section at $\mathrm{AB}$, and it was logged during IODP Expedition 360. 
Both oxide- and olivine-gabbro are also prevalent in the $157 \mathrm{~m}$ deep Hole $1105 \mathrm{~A}$ drilled at AB during ODP Leg 179, about a km NE of Hole 735B (Pettigrew et al. 1999). At AM, Hole U1309D extends $1415 \mathrm{~m}$ into the domal core of the complex and it was logged in stages during IODP Expeditions 304, 305, and 340T (Blackman et al. 2006; Expedition 340T Scientists 2012). The recovered core is somewhat more variable than at $\mathrm{AB}$ and consists of gabbro (56\%), olivine gabbro (25\%) and several percent each of olivine-rich troctolites, troctolites, oxide gabbros, and diabase. Details of the physical property logging and corresponding core sample results for Holes 735B and U1309D have been published previously (Iturrino et al. 2002; Collins et al. 2009; Blackman et al. 2014; Harding et al. 2016) and we summarize those findings below. New AB results from Hole U1473A are reported in more detail. Also, new determinations of U1473A and U1309D (at AM) core sample velocities at pressures up to $200 \mathrm{MPa}$ are reported. Following the description of the logging and relevant core measurements, we compare and contrast the results and discuss possible implications for recognizing core complex evolution at $\mathrm{AB}$ and $\mathrm{AM}$.

\section{Observations}

\section{Hole U1473A, AB}

Drilling of Hole U1473A in AB was challenging due to several fractured intervals where borehole stability and recovery were poor (MacLeod et al. 2017). Despite the challenges, core recovery was good overall, 59\%, and logging of the borehole was accomplished over essentially the full $\sim 800 \mathrm{~m}$ depth attained during Expedition 360 (Fig. 2). Physical properties of the recovered rock were obtained by shipboard measurements (room/Standard Temperature and Pressure, STP) on $8 \mathrm{~cm}^{3}$ cubes cut from representative petrologic units throughout the section (MacLeod et al. 2017); we refer to these sample porosity, density, and P-wave velocity ( Vp) data in this paper. Sonic logging runs included a pass in cross dipole mode to assess seismic anisotropy of the section, in addition to velocity. Triple combo logging 
runs included wallrock density, resistivity and borehole caliper measurements which are discussed here, as well.

\section{Fig. 2}

Downhole data for IODP Hole U1473A at AB, SWIR. Lithology determined by visual core description, color code at right. Logging runs show borehole width and condition (black: single caliper triple combo run; red/magenta: 2-caliper FMS run1; blue/cyan- FMS run3). Right two panels show 2-m running average of wallrock density and seismic velocity 


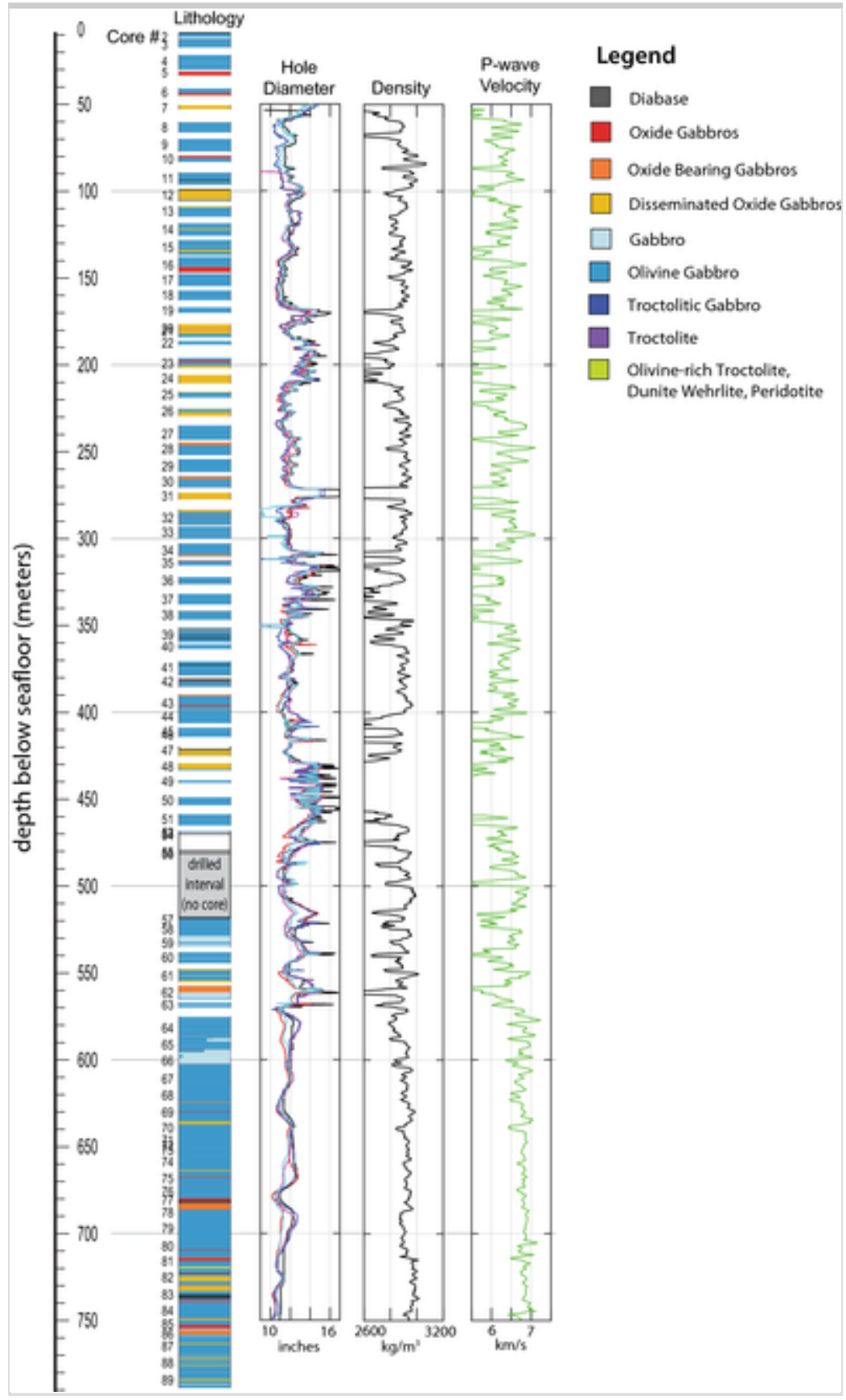

AQ2

Overall, the wallrock density and Vp are typical for gabbros$2850-2900 \mathrm{~kg} / \mathrm{m}^{3}$ and $6-7 \mathrm{~km} / \mathrm{s}$, respectively. Downhole velocity variability of $\pm 0.5 \mathrm{~km} / \mathrm{s}$ is common over 5-10 m intervals in the upper $580 \mathrm{~m}$ of the section and this is probably real, based on the sufficiently 
good borehole condition away from recognized fractured zones. Velocities are generally lower, $\sim 6.4 \mathrm{~km} / \mathrm{s}$, at depths less than $580 \mathrm{mbsf}$, whereas $\mathrm{Vp}$ averages $\sim 6.9 \mathrm{~km} / \mathrm{s}$ below that depth. Mean $\mathrm{Vp} / \mathrm{Vs}$ ratio for the full section is $1.8 \pm 0.08$, with variability about the mean dropping from \pm 0.1 above $580 \mathrm{mbsf}$ to \pm 0.03 at greater depths.

The presence of alteration veins correlates with the amplitude of density and velocity variability, as expected given the observed (MacLeod et al. 2017) clay, carbonate, or secondary amphibole fill compositions. The mean thickness of these veins averages $0.13 \mathrm{~cm}$, with just two instances where a vein exceeds $2 \mathrm{~cm}$ in the recovered core. Veins up to $2 \mathrm{~cm}$ thick were not uncommon in the upper $100 \mathrm{~m}$; mean thickness of $0.3-1 \mathrm{~cm}$ is not uncommon in the 100-300 mbsf interval. Below that, almost all veins in the recovered core were less than $0.2 \mathrm{~cm}$ in mean thickness. Most of the core from shallower than 580 mbsf was characterized as having an intensity of $1-5$ veins per $10 \mathrm{~cm}$. Below that depth, typical intensity drops to $<1$ vein per $10 \mathrm{~cm}$, except for an increase at $630-650 \mathrm{mbsf}$, below which the section is free of clay and carbonate veins (MacLeod et al. 2017). In this deepest section, logged velocities are more constant and the variation that does occur coincides with isolated vein(s) identified in the core and/or logged as spikes in gamma radiation (5-7 gAPI relative to background level of $<2$ gAPI). Density in this deepest region shows some relation to core sample oxide content, although it is not simple. Oxide content was typically estimated by macroscopic core description, with occurences of locally increased concentration guided by along-core magnetic susceptibility plots. Density values somewhat greater than $2900 \mathrm{~kg} / \mathrm{m}^{3}$ are typical from 580 to $685 \mathrm{mbsf}$, they drop below $2900 \mathrm{~kg} / \mathrm{m}^{3}$ for the olivine gabbro interval $685-710 \mathrm{mbsf}$, and then increase to almost $3000 \mathrm{~kg} / \mathrm{m}^{3}$ where oxide content is notable, to $\sim 740 \mathrm{mbsf}$ (Fig. 2). This downhole pattern is not mirrored in $\mathrm{Vp}$, which would not be surprising if oxide dominates the density signal, since oxide gabbro velocity is lower than that of olivine gabbro (Iturrino et al. 2002).

The U1473A cross dipole sonic log data were processed to determine 
anisotropy using the post-processing module in Schlumberger's Techlog software. Shear waves and their slowness are identified/determined by that algorithm, and rotation to obtain the polarization direction of the fast shear wave is solved. Not surprisingly, intervals that might have been most interesting in terms of anisotropy signature were those where fracturing degraded the borehole condition, so reliable results were not obtained. Outside of these zones, several intervals that are $10^{\prime} \mathrm{s} \mathrm{m}$ in length display relatively constant azimuth of fast shear wave propagation $\left(\sim \mathrm{N} 20^{\circ} \mathrm{W}\right.$, Figure S1) with low anisotropy magnitude $\sim 1 \%$. Just a few meter-scale intervals indicate larger anisotropy, 3-4\%, at subseafloor depths of 335, 410 , and $545 \mathrm{mbsf}$. The two shallower intervals are associated/bounded by faults documented in the core so deformation-controlled porosity likely is responsible for the anisotropy. Between 541 and $548 \mathrm{mbsf}$, visual core description (Macleod et al. 2017) indicates a fault, underlain by a zone of increased veining, both within olivine gabbro, which overlies oxide gabbro for which the upper contact was not recovered. So, deformation related orientation of porosity probably is responsible for the logged seismic anisotropy.

Core sample measurements at STP (MacLeod et al. 2017) document an expected general decrease in $\mathrm{Vp}$ as porosity increases in Hole U1473A but there is considerable scatter (Fig. 3a). Similarly, primary mineralogy is not a consistent factor in the measured core sample velocity, as indicated by the lack of clean trend of Vp with change in olivine mode (Fig. 3b), although olivine content does play a role. Gabbro samples (olivine mode $<$ 5) have average $\mathrm{Vp}$ of $6.59 \mathrm{~km} / \mathrm{s}$ whereas the average for olivine gabbros (mode 5-17 in the U1473A sample set) is $6.74 \mathrm{~km} / \mathrm{s}$. Alteration plays a more important role in reducing velocity for these samples, mean $\mathrm{Vp}$ values dropping on the order of $0.18 \mathrm{~km} / \mathrm{s}$ for every $10 \%$ increase in overall alteration, as visually estimated (MacLeod et al. 2017).

\section{Fig. 3}

Hole U1473A core sample physical properties measured at STP (MacLeod et al. 2017). a Velocity shows broad decrease with increasing porosity, also 
significant scatter. b Velocity shows very slight dependence on olivine mode in this $0-800$ mbsf section
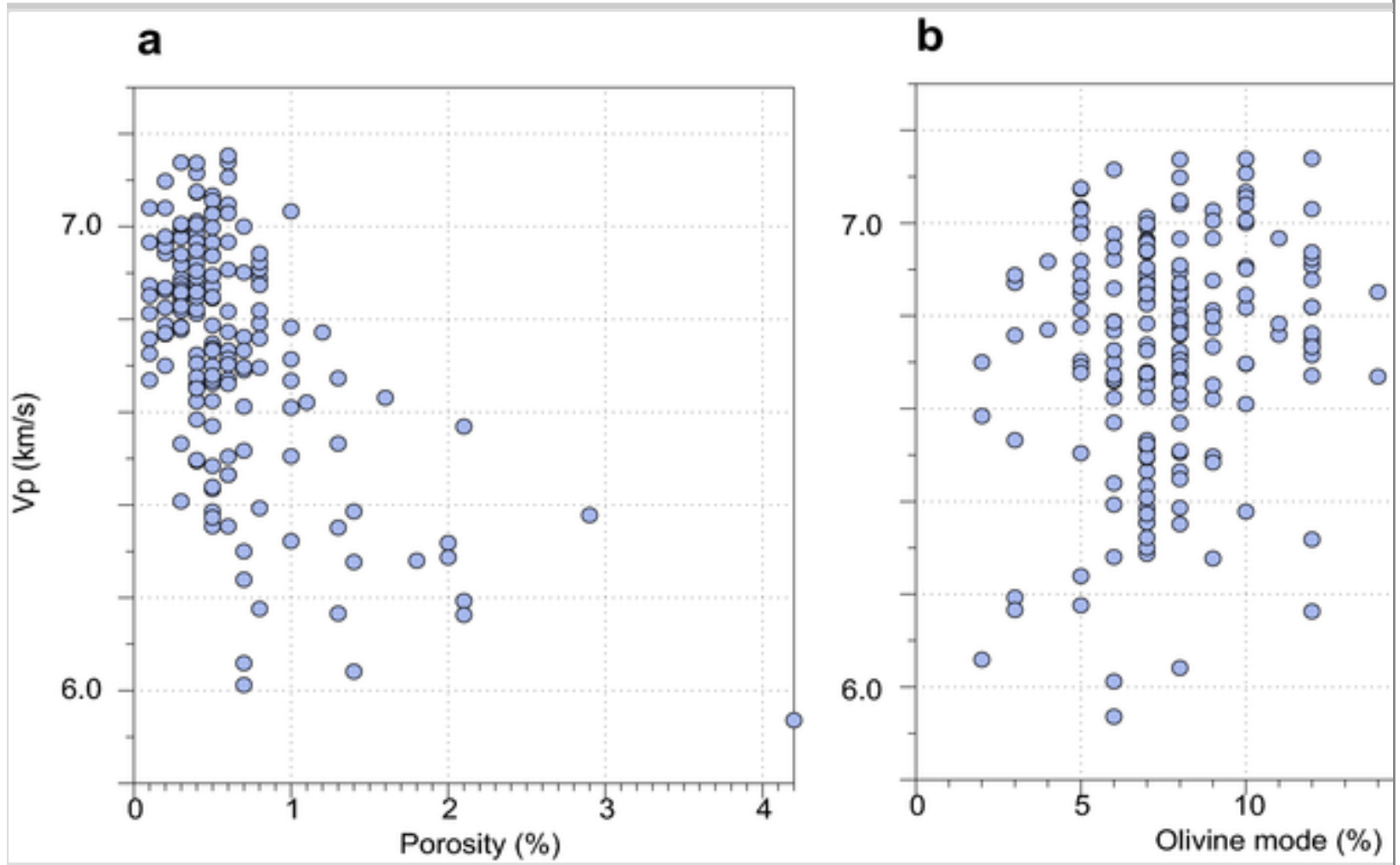

\section{Hole U1309D, AM}

Site U1309 in the footwall to the Central Dome detachment at AM comprises a gabbroic sequence that is probably $\sim 4 \mathrm{~km}$ thick (Harding et al. 2016; Blackman and Collins 2010). Results of post-drilling seismic survey data analysis, employinged downward continuation of streamer refraction data and waveform inversion, are consistent with the borehole data at the scale of imaging resolution (order 100-200 m, Harding et al. 2016). In the upper, drilled section, an overall increase in seismic velocity with depth is punctuated by local reductions, where alteration is locally high and/or deformation structures are more intense (Blackman et al. 2014). Vp increases from $\sim 4$ to $6 \mathrm{~km} / \mathrm{s}$ from the seafloor to $350 \mathrm{mbsf}$, showing significant variability at meter(s) scale (Fig. 4). Average Vp is $6.0 \mathrm{~km} / \mathrm{s}$ in the $350-800 \mathrm{mbsf}$ interval where variation is still significant 
(as much as $\pm 1 \mathrm{~km} / \mathrm{s}$ ). The lower part of the section, 800-1400 mbsf, has $\mathrm{Vp}$ of $6.6 \mathrm{~km} / \mathrm{s}$ on average, with generally smaller meter-scale variability. The olivine-rich troctolite interval at 1080-1220 mbsf averages $\sim 1 \mathrm{~km} / \mathrm{s}$ slower than the surrounding section due to generally much greater alteration in that interval (Figs. 4 and 5), although local variation in the extent of serpentinization is significant (Fig. 5). The boundaries between petrologic units tend to show drops in $\mathrm{Vp}$ and, as expected, intervals where serpentinization is nearly complete (total alteration $80-100 \%$ ) are associated with local dip in $\mathrm{Vp}$.

Fig. 4

Downhole data for IODP Hole U1309D, at AM, MAR. Lithology determined by visual core description. Logging runs show borehole width/condition, and 2-m running average of wallrock density and seismic velocity. Exp 305 sonic log shown by purple curve and Exp 340T, 7 years later, is shown by red curve. Plot scales and lithology key are same as in Fig. 2 


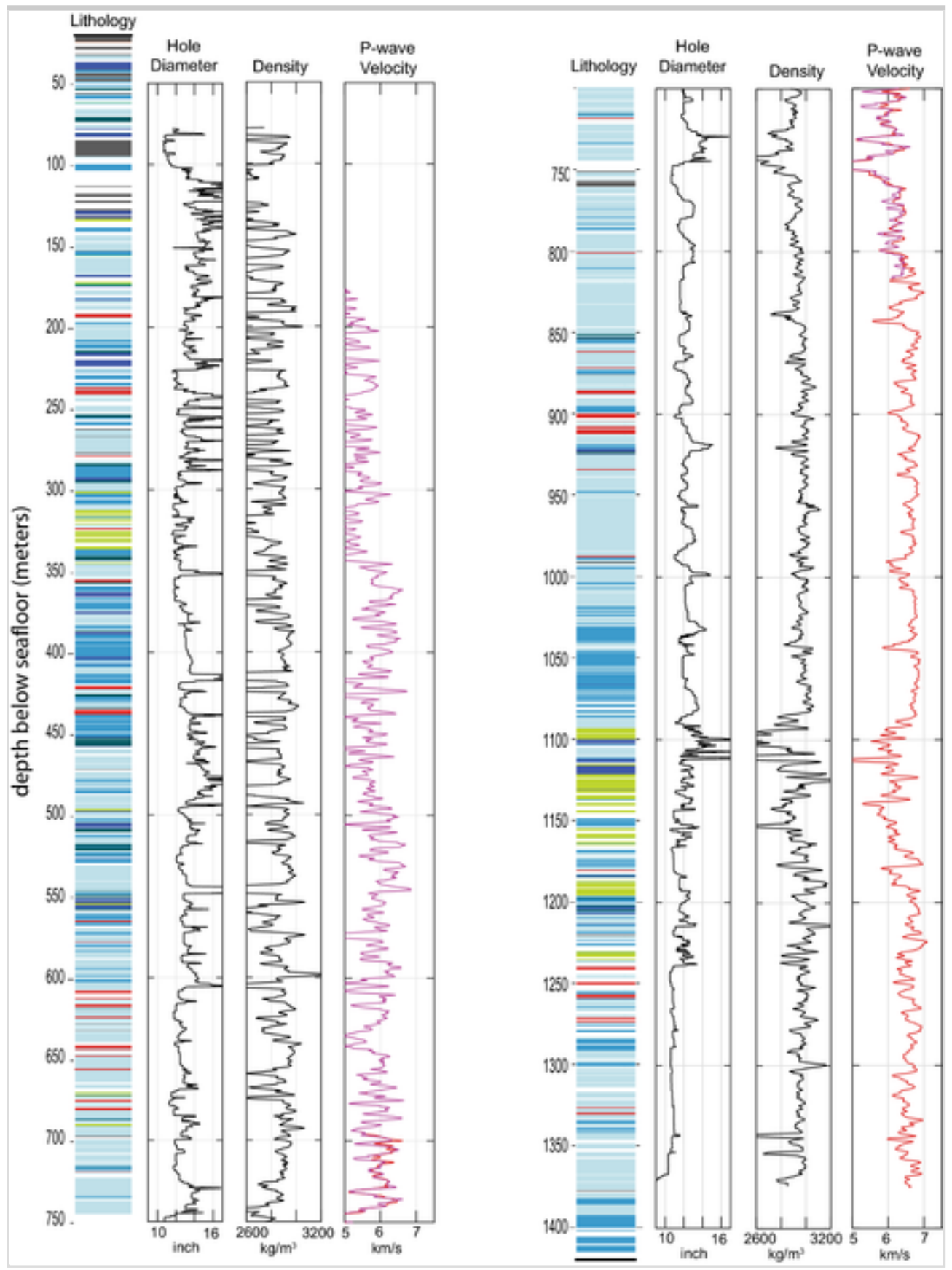

\section{Fig. 5}

Relation between primary and secondary lithology and P-wave velocity, shown for the deeper olivine-rich troctolite interval in Hole U1309D. Lithology shown at left is based on petrologic units described during Exp $304 / 305$, as was the total alteration of core pieces (black symbols in right panel). Red curve shows the sonic log data with no downhole averaging. 
Correspondence of depths between core and log may be uncertain by up to 1-2 $\mathrm{m}$, still a common correlation between $\mathrm{Vp}$ variability and alteration is evident. Figure S2 shows the same data with depth scale expanded to aid core-log comparison

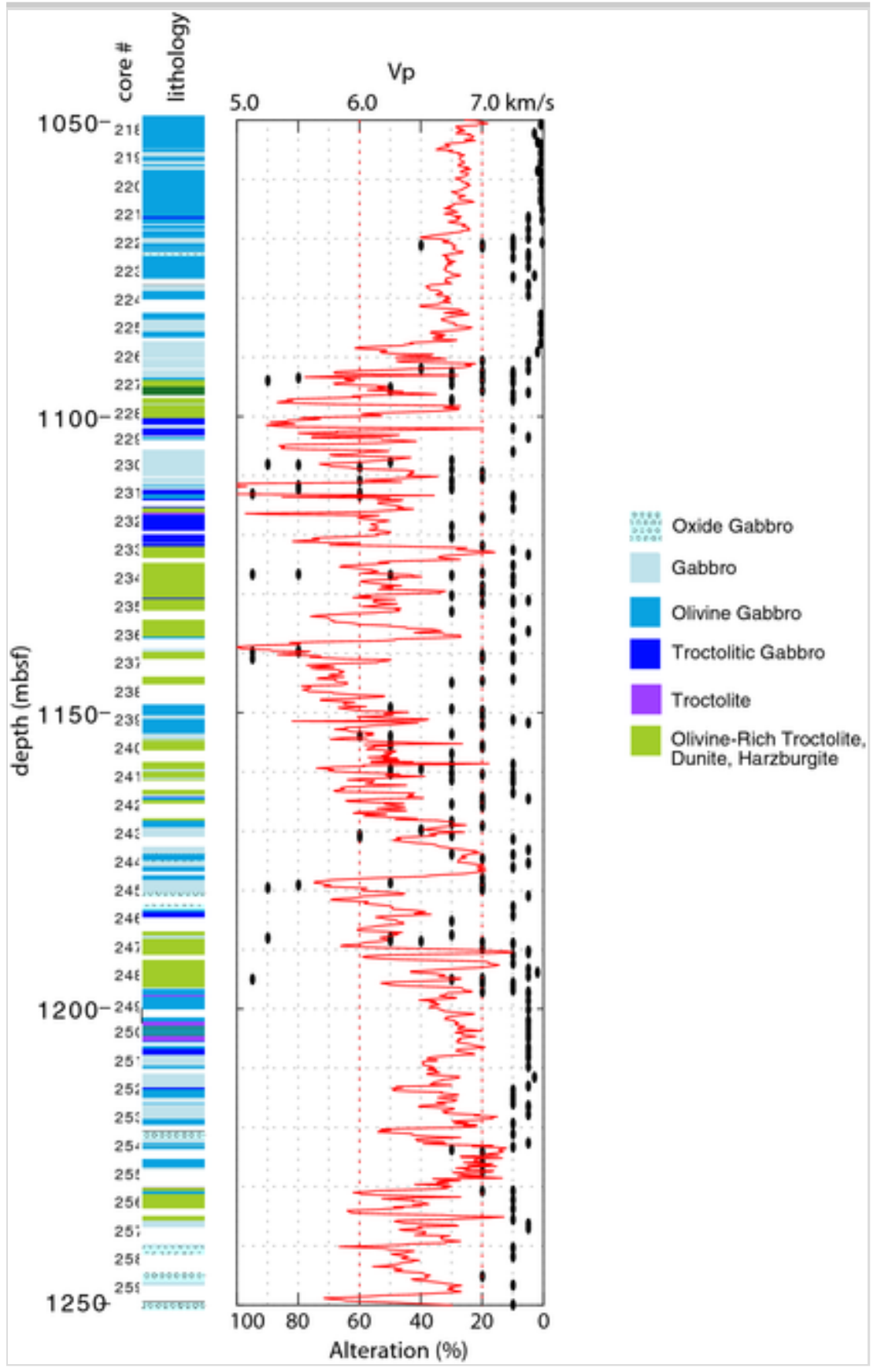

A fault at 746 mbsf has a damage zone extending at least $20 \mathrm{~m}$ below, and 
possibly as much as that above (depending how much borehole degradation has impacted data quality) where $\mathrm{Vp}$ is $1-2 \mathrm{~km} / \mathrm{s}$ lower than surrounding wallrock (Fig. 4). Low return and the presence of ultracataclasite (thin black interval in lithology column of Fig. 4) in the 17\% that was recovered, along with analysis of images of borehole structure document this fault (Michibayashi et al. 2008). Diabase (gray at $760 \mathrm{mbsf}$ in Fig. 4) intruded the section right at the base of the reduced Vp zone associated with this fault.

Cross dipole sonic log data for Expedition 340T covers the lower $\sim$ half of the section and these data were processed the same way as the Hole U1473A data. For most of this lower section, the polarization direction of the fast shear wave is variable, a given value consistent only along intervals $<\sim 5 \mathrm{~m}$ in length; the magnitude of anisotropy is low overall (generally $<2 \%$; Figure S1). Only in the 900-1080 mbsf interval, where a fairly uniform gabbroic sequence occurs, is there a constant fast azimuth $\left(\mathrm{N} \sim 70^{\circ} \mathrm{W}\right)$ with anisotropy magnitude $\sim 1.5 \%$. Two meter-scale intervals where anisotropy reaches $3-6 \%$ occur in the olivine-rich troctolite zone 1090-1200 mbsf.

\section{In-situ velocity/density of OCC gabbroic rocks at lower crustal depth}

Selected core samples from Hole U1309D were analyzed at pressures simulating conditions throughout the crust, to estimate in situ Vp for a multi-km thick gabbroic sequence. Results for $200 \mathrm{MPa}$ ( $\sim$ Moho depth for a standard ocean crustal section) were part of the seismic results reported by Collins et al. (2009). An error in the calibration used to compute those values was recognized recently, so we report corrected values here, along with showing how measured $\mathrm{Vp}$ on these samples varies as confining pressure is increased from 0 to $200 \mathrm{MPa}$. We analyze these results together with prior measurements made on gabbroic samples from ODP Holes 735B (AB), Hole 923 A (70 m deep, Kane OCC) and Hole 894G (154 m deep, Hess Deep). 
Hole U1309D rocks that were originally olivine-rich, either troctolite or olivine gabbro with more than $20 \%$ modal olivine, show a linear trend of increasing Vp $(5.6-6.5 \mathrm{~km} / \mathrm{s})$ with increasing density $\left(2650-2800 \mathrm{~kg} / \mathrm{m}^{3}\right.$, Fig. 6a). Most of the samples from this and the other sites scatter at higher value, in the ranges $6.5-7.5 \mathrm{~km} / \mathrm{s}$ and $2800-3040 \mathrm{~kg} / \mathrm{m}^{3}$, although the broad increase of $\mathrm{Vp}$ with density does continue the same basic trend as the originally olivine-rich samples. There is no clear pattern in Vp at $200 \mathrm{MPa}$ with respect to gabbro sample depth. All but the U1309D highly altered olivine-rich samples, which occurred within the olivine-rich troctolite zone $\sim 290-350 \mathrm{mbsf}$, vary throughout the $6.5-7.5 \mathrm{~km} / \mathrm{s}$ range (Fig. 6b).

\section{Fig. 6}

Properties of core samples from gabbroic sections obtained by deep sea drilling, at room temperature. Density measured at room pressure and $\mathrm{Vp}$ measured at $200 \mathrm{MPa}$. Symbols/color are keyed to (I)-ODP Hole as indicated in legend on top panel. The lower density/velocity values correspond to a highly altered, olivine-rich troctolite interval in Hole U1309D. a Vp as a function of bulk density. b Vp versus depth in borehole 


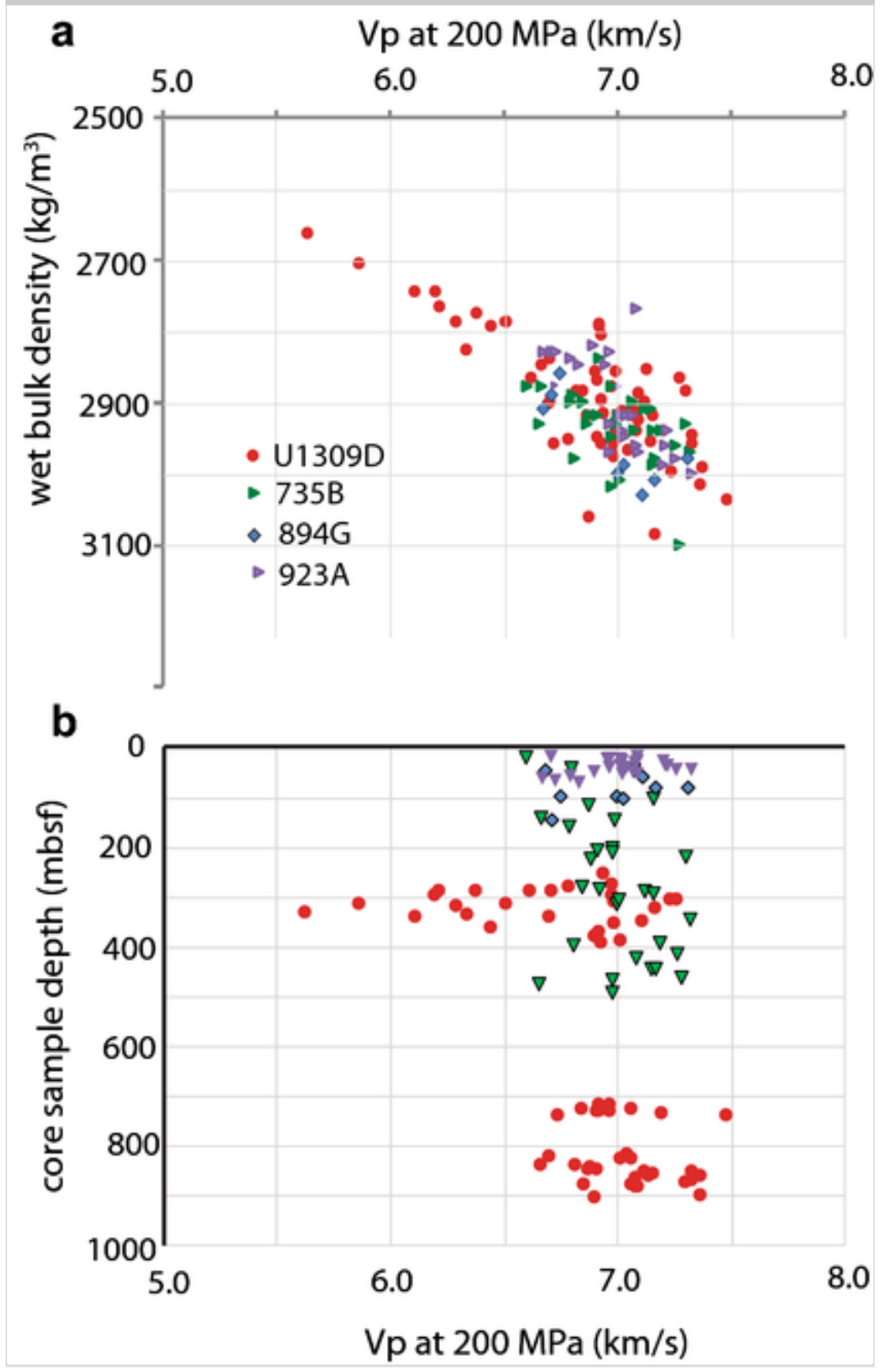

The increase in velocity with pressure was determined for each sample suite (Carlson and Miller 2004; Collins et al. 2009). Curves predicting the average increase in $\mathrm{Vp}$ with the natural log of estimated depth (Carlson and Miller 2004) were fit assuming an increase of $1 \mathrm{~km}$ per $20 \mathrm{MPa}$ pressure increase. For Hole U1309D, gabbroic samples alone have average 
velocity about $0.1 \mathrm{~km} / \mathrm{s}$ higher than the full sample set tested (Fig. 7a). Predicted curves fit each sample set well and display $\sim 0.5 \mathrm{~km} / \mathrm{s}$ higher velocity in the upper $1-2 \mathrm{~km}$ of the crust that characterizes shallow gabbroic sequences, relative to the more typical upper crustal diabase (e.g. Hole 504B in crust formed at the East Pacific Rise), as shown in Fig. 7b.

Fig. 7 legend in Figure 7b has incorrect year in Cary \& Chapman reference- it should be 1988

Velocity of core samples as a function of depth, as measured in a series of lab runs at TAMU where confining pressure was increased incrementally and then values were measured again as pressure was incrementally decreased (Supplementary Material, Tables S1 and S2). a Corrected calibration for U1309D gabbro sample values with standard error shown, and curve fit solution for all rock types tested from that hole. b Curve fit solutions for sample suites from several gabbroic sections drilled by (I)ODP (735B, 894G, and 923A data from Carlson and Miller 2004). Seismic refraction data from various Atlantic studies are shown in gray curves, with crustal age and sources identified in legend. These selected expanding spread profile data have good velocity control and are located away from fracture zones 


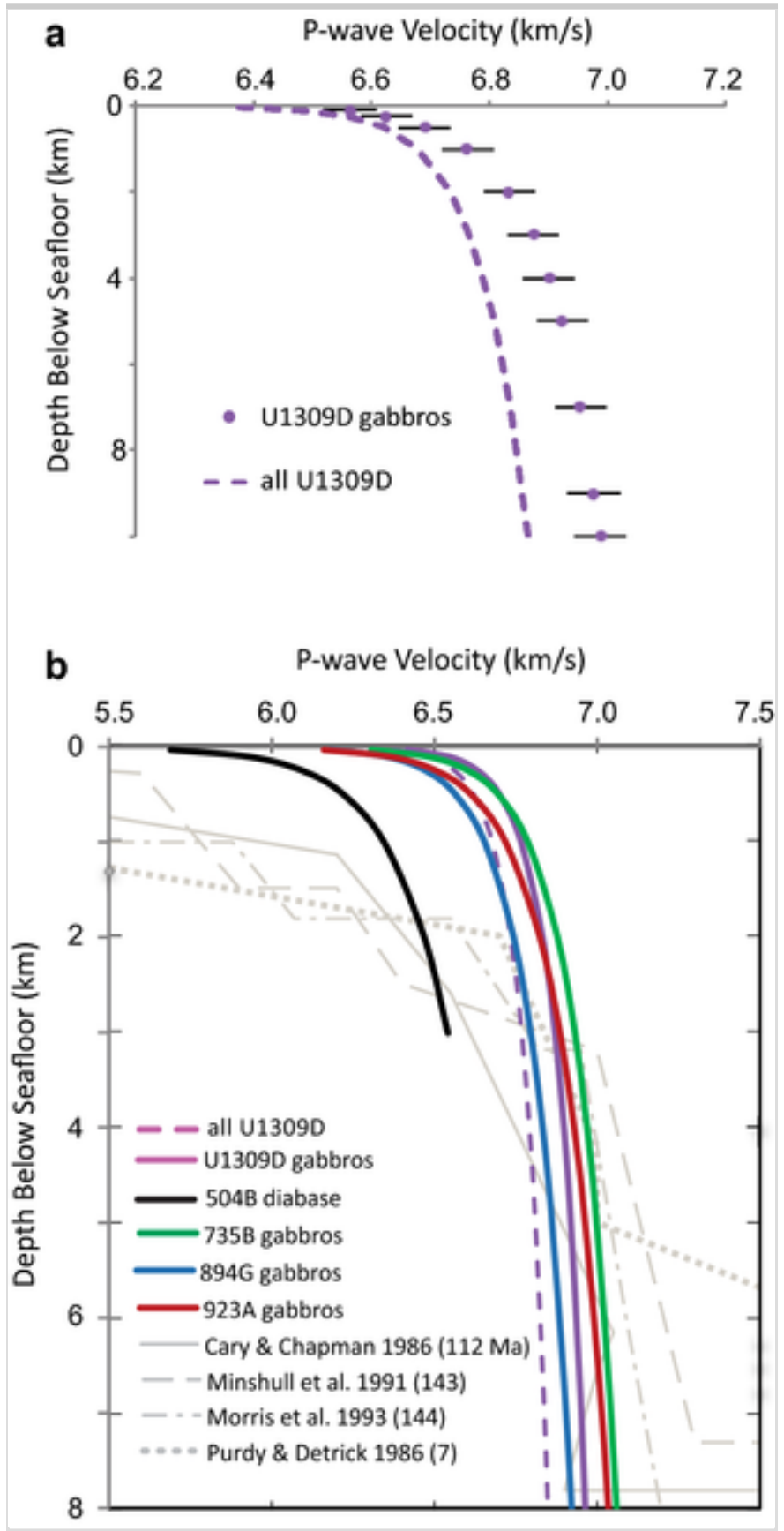

Differences between the velocity-depth curves for the different gabbroic sequences that have been drilled (Fig. 7b) indicate that alteration experienced by young intrusive oceanic crust would have a long-term velocity reduction effect as great as $0.25 \mathrm{~km} / \mathrm{s}$. Both the AM (U1309D) full dataset and the Hess Deep (894) dataset include more highly altered 
samples than the other datasets and the curves that fit these data predict lower velocity. Results to date suggest that the thickness of the affected interval in young ocean lithosphere may be on the order of 800-1000 m, although drilling coverage is not currently sufficient to constrain the actual penetration of hydrothermal circulation and associated alteration. If there are fractures that extend to full crustal depths (several $\mathrm{km}$ ) and there are intervals with olivine content $20 \%$ or greater, the velocity reduction due to associated seawater alteration would persist at depth as the plate ages.

\section{Comparison of $\mathrm{AB}$ and $\mathrm{AM}$}

The core complex data from AM and AB display differences in physical properties, for which primary lithology appears to play some role but deformation and alteration history are controlling factors. The shipboard sample data (Fig. 8) indicate that seismic velocity is consistently lower at $\mathrm{AM}$ than at $\mathrm{AB}$, despite bulk and grain density having significant overlap between the sites. Post expedition measurements of selected U1473A and U1309D samples using instrumentation aboard the Chikyu (Abe et al. 2018) confirm that the prior shipboard results do not simply reflect an unrecognized change in lab calibration on the JOIDES Resolution.

\section{Fig. 8}

Core sample porosity and Vp. a Comparison of prior (Iturrino et al. 2002; Blackman et al. 2006) and new (Macleod et al. 2017; Abe et al. 2018) properties at STP for AB and AM. Red curve should be red, not gray, in Figure 7a ... curve shows Vp:-Porosity prediction following formulation developed by f(Carlson 2010; Carlson 2014); see Supplementary Material). b Core sample (black dot) and logged Vp (10-m average, red) in Hole U1309D. (c-d) Raw log (red, magenta) and sample Vp for 2 intervals at lab pressure of 0 (black dot), 10 (blue + ), and $100 \mathrm{MPa}$ (green o) 

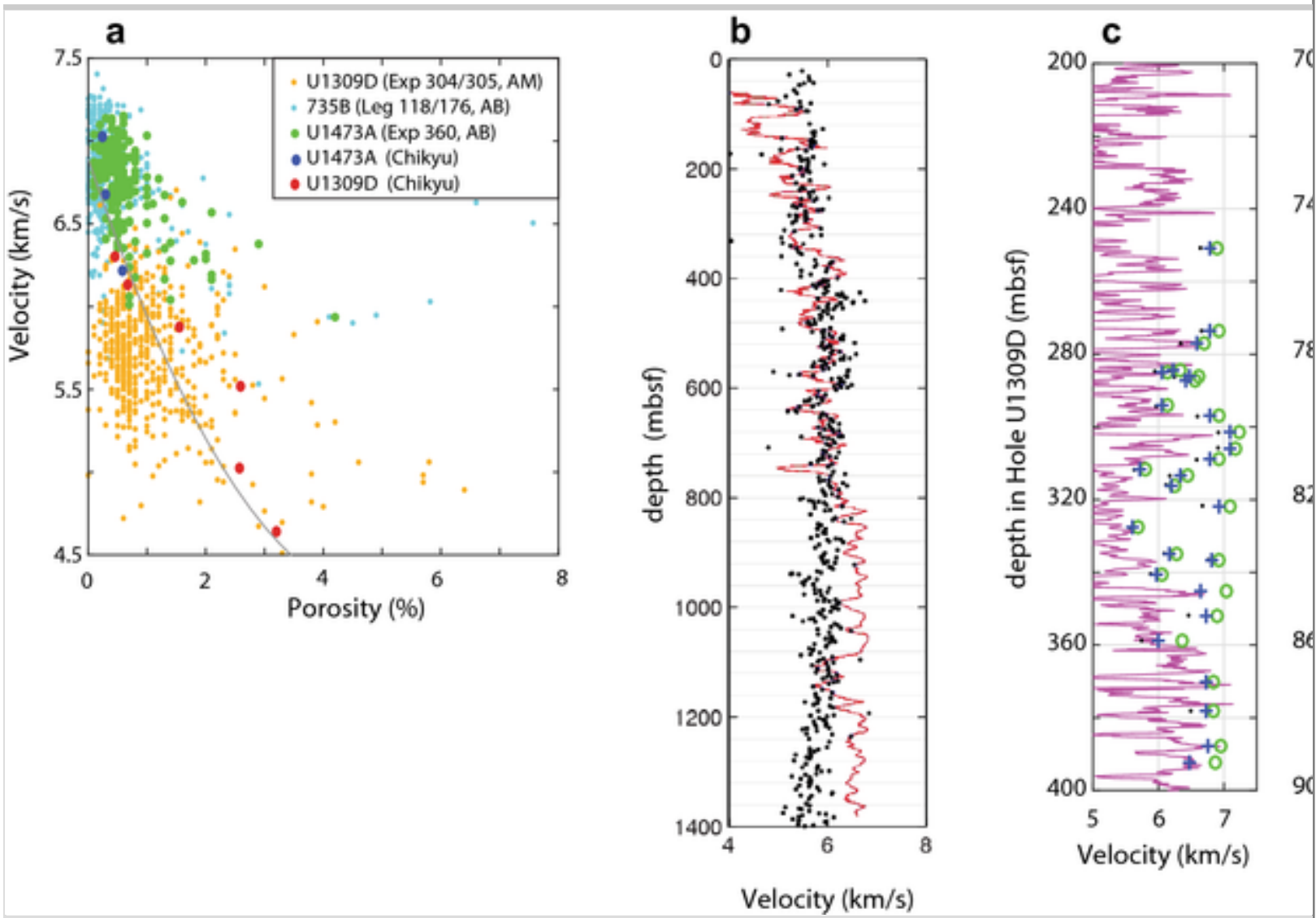

Porosity of the core samples is a major factor in the reduced $\mathrm{Vp}$ values at AM, compared to AB samples. Shipboard determinations of sample porosity are several percent higher in some of the AM section and this is one reason for the difference (Fig. 8a). Importantly, samples from deeper than $\sim 800$ mbsf in Hole U1309D show a steady decreasing Vp trend with depth, which is not observed in the borehole log (Fig. 8b). Hole 735B samples do not exhibit such a decrease in $\mathrm{Vp}$ for the lower part of the section (no log data are available for comparison at this site). We infer that Hole U1309D samples are currently under a combination of lithostatic and tectonic loads which, when released through drilling and recovery, results in microcracking that reduces Vp from the in situ value. Such effect has been noted in prior investigations of deep, hard rock core from the Pacific (Carlson, 2014). Current conditions at Site 735 in the 800-1500 mbsf interval must be such that sample unloading effects are minor. Larger 
fractures affect in situ $\mathrm{Vp}$ at depths to several hundred meters below seafloor, where core sample values are almost always higher than log values (Fig. 8c, U1309D; Macleod et al. 2017, U1473A). These are not a factor at greater depths where lab $\mathrm{Vp}$ tracks logged value quite well (e.g. Fig. 8d; Macleod et al. 2017). Logged velocity is sensitive not only to effective properties that reflect distributed small cracks/porosity across the $2-\mathrm{m}$ tool length, but also to features with size ranging up to many $\mathrm{cm}$. Core samples, on the other hand, are chosen to avoid visible fractures and measurement of velocity on these cubic-2-cm pieces is sensitive to $\mu \mathrm{m}$ to sub-mm scale porosity.

In the upper $\sim 800 \mathrm{~m}$, differences in primary composition and/or the respective alteration histories probably also contribute to the reduced sample $\mathrm{Vp}$ at $\mathrm{AM}$ compared to $\mathrm{AB}$. The latter is dominated by olivine gabbro (modal percent olivine $>5 \%$ ) whereas the upper kilometer and a half of AM comprises dominantly gabbro. Carlson et al. (2009) showed that the influence of olivine content on seismic velocities in gabbros depends on the $\mathrm{Mg \#}$ as well as the degree of alteration to serpentine. In light of the comparatively high Mg numbers of the OCC samples (75-85), a greater olivine content would correspond to higher $\mathrm{Vp}$ in unaltered samples. While amounts are modest, AM contains several troctolite intervals and significant fractions of the olivine within these units are extensively altered, thereby lowering Vp overall despite (primary) olivine content being locally high.

The upper $\sim 600-800$ mbsf at both the AB and AM OCCs show greater variability in $\mathrm{Vp}$ than the underlying sections penetrated by seafloor drilling and this pattern probably reflects detachment-related processes (Fig. 9). The thickness of the deformation zone associated with detachment faulting at OCCs has been shown to be several hundred meters (Dick et al. 2000; John and Cheadle 2010; Blackman et al. 2014; Harding et al. 2016), with the intensity of impacts being greatest in the 200-400 m immediately beneath the fault (Schroeder and John 2004; Karson et al. 2006; Escartín et al. 2003). The association that we find between Vp variability, on the 
meter-scale downhole, and the intensity of alteration veins indicates that seawater circulation is enabled by the detachment-induced deformation and footwall exposure. The fluid flow extends to depths of at least $800 \mathrm{mbsf}$ and persists long enough for reaction with the rock to leave a physically (and chemically) detectable record.

\section{Fig. 9}

Comparison of AB Holes 735B, U1473A, and AM Hole U1309D downhole data. Lithology shown as $20-\mathrm{m}$ running average of recovered core. Alteration and deformation determined by visual core description on each expedition, with same intensity scale. All velocity depth curves are plotted together in center panel: dark green U1473A sonic log (10-m average); light green 735B sonic log (no ave, Iturrino et al. 2002); purple- U1309D sonic log (10-m ave.); gray- histogram of FullWave Inversion model within $1 \mathrm{~km}$ of U1309D (Harding et al. 2016); magenta- representative FWI curve for Southern Ridge of AM for comparison with Central Dome at Hole U1309D. Faulted intervals are marked by thick gray-green lines for U1473A and U1309D 


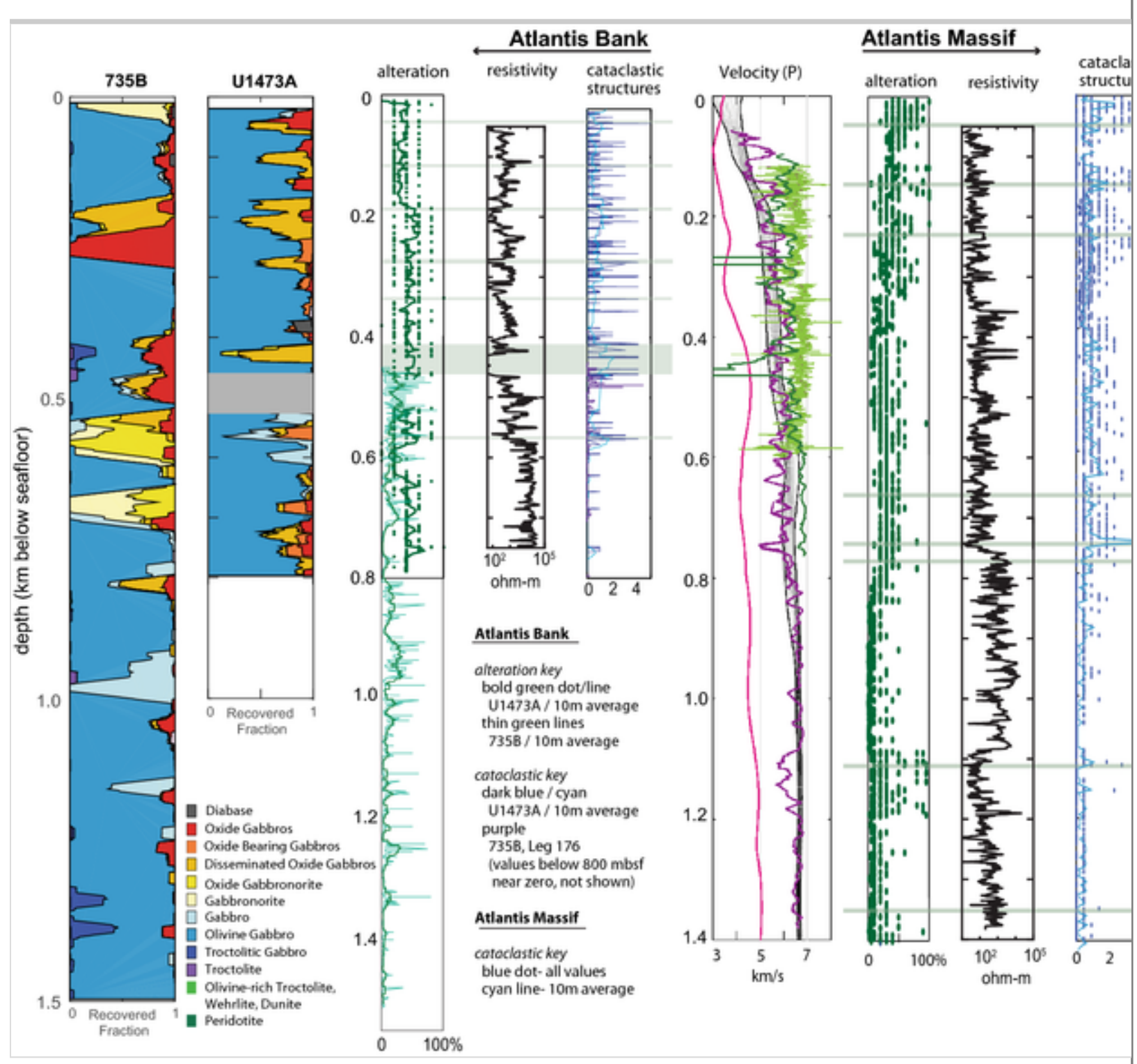

Since AB is a wave-cut platform covered by carbonate deposits (Robinson and von Herzen 1989), it is unclear how much of the original section from just below the exposed detachment fault has been eroded away. Relationships between the core recovered from Hole U1473A and Hole 735B and 1105A suggest that faulting within the bank may vertically offset these sequences by a up to a few hundred meters (MacLeod et al. 2017) so only rough depth correlation between the AB Sites is possible. Regardless, removal of a couple hundred meters of the detachment deformation zone could explain why cataclastic structures in the core from AB drop notably 
at a shallower depth than at AM- somewhat $<600$ mbsf versus $\sim 800$ mbsf, respectively. We cannot rule out the possibility that the detachment fault systems at $\mathrm{AB}$ and $\mathrm{AM}$ simply had different deformation distributions with depth. The occurrence of troctolites in the AM sequence and its proximity to a serpentinite-dominated domal core (the middle and western portion of the Southern Ridge, Henig et al. 2012; Harding et al. 2016; Früh-Green et al. 2016), may indicate that magmatic conditions and possibly the interplay with faulting differed between the two OCCs (Escartín et al. 2003). Certainly, the extent of high temperature plastic deformation in the upper couple hundred meters of $\mathrm{AB}$ at Hole $735 \mathrm{~B}$ is greater than that observed in the upper part of Hole U1309D (Ildefonse et al. 2007).

The similarity of depth to which Vp variability extends at $\mathrm{AB}$ and $\mathrm{AM}$ and the association of this variability with alteration veins suggests that effects of long-term aging on a ridge flank do not overwhelm signatures that develop as an OCC forms. Differences in the balance of magmatic/tectonic activity between the sites might be expected. While Despite AB having formed at an ultraslow spreading rate, Dick et al. (2000) conclude that melt supply in this segment center was higher than typical for most the SWIR. AM formed at the end of a slow-spreading segment and magmatism is interpreted to be episodic due to reduced melt supply far from the segment center (Blackman et al. 2011; Henig et al. 2012). Recent petrologic, geochemical, and structural analysis reported by Dick et al. (2019) support a fundamental difference in melt, crystallization, and accretion dynamics between $\mathrm{AB}$ and $\mathrm{AM}$. However, while the associated differences in igneous stratigraphies might explain a modest offset in $\mathrm{Vp}$ between the sites, it cannot explain the observed consistent depth extent of variabilty in $\mathrm{Vp}$.

Borehole logs indicate that $\mathrm{Vp}$ of $6.9 \mathrm{~km} / \mathrm{s}$ would likely characterize gabbroic bodies within the upper kms of OCC if faulting and alteration have not significantly affected them. For each of Holes 735B, U1473A, and U1309D, this value dominates the log at depths where cataclastic structures and alteration are generally quite low $(<1$ vein per $10 \mathrm{~cm}$, minor 
fracturing). The uncertainty in the full waveform inversion also collapses for this part of the section at AM (Fig. 9, center panel), suggesting that advanced processing of multi-channel seismic data (Harding et al. 2016; Canales et al. 2008; Canales 2010; Xu et al. 2017) can provide some constraint on the extent of hydration within undrilled portions of OCC gabbro bodies.

\section{Publisher's Note}

Springer Nature remains neutral with regard to jurisdictional claims in published maps and institutional affiliations.

\section{Acknowledgements}

This research used samples and data provided by the International Ocean Drilling Program and the International Ocean Discovery Program. Funding for this work was provided by the National Science Foundation, via the US Science Support Program (DKB, AH).

\section{Electronic supplementary material}

Below is the link to the electronic supplementary material.

Supplementary material 1 (DOCX $108 \mathrm{~kb})$

Supplementary material 2 (EPS $7759 \mathrm{~kb}$ )

Supplementary material 3 (EPS $3040 \mathrm{~kb}$ )

\section{References}


Abe N, Hirose T, Katayama I, Hatakayama K, Akamatsu Y (2018) IODP Expedition 360 postcruise research presentation, Sicily, May 2018 (this reference will be replaced by IODP Data Report, in prep)

Blackman DK, Collins JA (2010) Lower crustal variability and the crust/mantle transition at the atlantis massif oceanic core complex. Geophys Res Lett. https://doi.org/10.1029/2010GL045165

Blackman DK, Karson JA, Kelley DS, Cann JR, Früh-Green GL, Gee JS, Hurst S, Morgan J, Nooner SL, Ross DK, Schroeder T, Williams EA (2002) Geology of the Atlantis Massif (MAR $\left.30^{\circ} \mathrm{N}\right)$ : implications for the evolution of an ultramafic oceanic core complex. Mar Geophys Res 23:443-469

Blackman DK, Ildefonse B, John BE, Ohara Y, Miller DJ, MacLeod CJ, Expedition 304/305 Scientists (2006). In: Proceedings of the IODP 304/305: College Station TX (Integrated Ocean Drilling Program Management International, Inc.). https://doi.org/10.2204 /iodp.proc.304305.2006

Blackman DK, Ildefonse B, John BE, Ohara Y, Miller DJ, Abe N, Abratis M, Andal ES, Andreani M, Awaji S, Beard JS, Brunelli D, Charney AB, Christie DM, Collins J, Delacour AG, Delius H, Drouin M, Einaudi F, Escartín J, Frost BR, Früh-Green G, Fryer PB, Gee JS, Godard M, Grimes CB, Halfpenny A, Hansen HE, Harris AC, Tamura A, Hayman NW, Hellebrand E, Hirose T, Hirth JG, Ishimaru S, Johnson KTM, Karner GD, Linek M, MacLeod CJ, Maeda J, Mason OU, McCaig AM, Michibayashi K, Morris A, Nakagawa T, Nozaka T, Rosner M, Searle RC, Suhr G, Tominaga M, von der Handt A, Yamasaki T, Zhao X (2011) Drilling constraints on lithospheric accretion and evolution at Atlantis Massif, Mid-Atlantic Ridge $30^{\circ} \mathrm{N}$. J Geophys Res. https://doi.org/10.1029/2010JB007931

Blackman DK, Slagle A, Guerin G, Harding A (2014) Geophysical 
signatures of past and present hydration within a young oceanic core complex. Geophys Res Lett 41:1179-1186

Canales JP (2010) Small-scale structure of the Kane oceanic core complex, Mid-Atlantic Ridge $23^{\circ} 30^{\prime} \mathrm{N}$, from waveform tomography of multichannel seismic data. Geophys Res Lett. https://doi.org/10.1029 /2010g1044412

Canales J-P, Tucholke BE, Xu M, Collins JA, DuBois DL (2008) Seismic evidence for large-scale compositional heterogeneity of oceanic core complexes. Geochem Geophys Geosyst. https://doi.org /10.1029/2008GC002009

Cann JR, Blackman DK, Smith DK, McAllister E, Janssen B, Mello S, Avgerinos E, Pascoe AR, Escartín J (1997) Corrugated slip surfaces formed at ridge-transform intersections on the Mid-Atlantic Ridge. Nature 385:329-332

Carlson RL (2010) How crack porosity and shape control seismic velocities in the upper oceanic crust: modeling downhole logs from Holes 504B and 1256D. Geochem Geophys Geosys. https://doi.org /10.1029/2009GC002955

Carlson RL (2014) The effects of alteration and porosity on seismic velocities in oceanic basalts and diabases. Geochem Geophys Geosyst 15:4589-4598. https://doi.org/10.1002/2014GC005537

Carlson RL, Miller DJ (2004) Influence of pressure and mineralogy on seismic velocities in oceanic gabbros: implications for the composition and state of lower oceanic crust. J Geophys Res. https://doi.org/10.1029 /2003JB02699

Carlson RL, Miller DJ, Newman J (2009) The olivine enigma: or why alteration controls the seismic properties of oceanic gabbros. Geochem 
Geophys Geosyst. https://doi.org/10.1029/2008GC002263

Cary PW, Chapman CH (1988) Waveform inversion of expanding spread profile 5 from the north Atlantic transect. J Geophys Res 93:13575-13588

Collins JA, Blackman DK, Harris A, Carlson RL (2009) Seismic and drilling constraints on velocity structure and reflectivity near IODP Hole U1309D on the central dome of Atlantis Massif, Mid-Atlantic Ridge $30^{\circ} \mathrm{N}$. Geochem Geophys Geosys 10:1. https://doi.org/10.1029 /2008GC002121

Dick HJB, Schouten H, Meyer PS, Gallo DG, Bergh H, Tyce R, Patriat P, Johnson KTM, Snow J, Fisher A (1991) Tectonic evolution of the Atlantis II Fracture, Zone. In: Von Herzen RP, Robinson PT et al (eds) Proceedings of the ODP scientific results vol 118, pp 359-398, Ocean Drilling Program, College Station

Dick HJB, Natland JH, Alt JC, Bach W, Bideau D, Gee JS, Haggas S, Hertogen JGH, Hirth G, Holm PM, Ildefonse B, Iturrino GJ, John BE, Kelley DS, Kikawa E, Kingdon A, LeRoux PJ, Maeda J, Meyer PS, Miller DJ, Naslund HR, Niu Y-L, Robinson PT, Snow J, Stephen RA, Trimby PW, Worm H-U, Yoshinobu A (2000) A long in situ section of the lower ocean crust: results of ODP Leg 176 drilling at the Southwest Indian Ridge. Earth Planet Sci Lett 179:31-51. https://doi.org/10.1016 /S0012-821X(00)00102-3rr

Dick HJB, MacLeod CJ, Blum P, Abe N, Blackman DK, Bowles JA, Cheadle MJ, Cho K, Ciążela J, Deans JR, Edgcomb VP, Ferrando C, France L, Ghosh B, Ildefonse B, John BE, Kendrick MA, Kopke JH, Leong JAM, Liu C, Ma Q, Morishita T, Morris A, Natland JH, Nozaka T, Pluemper O, Sanfilippo A, Sylvan JB, Tivey MA, Tribuzio R, Viegas $\mathrm{G}$ (2019) Dynamic accretion beneath a slow spreading ridge segment: IODP Hole U1473A and the Atlantis Bank oceanic core complex. J 


\section{Geophys Res}

Escartin J, Smith DK, Cann J, Schouten H, Langmuir CH, Escrig S (2008) Central role of detachment faults in accretion of slow-spreading oceanic lithosphere. Nature 455:790-794. https://doi.org/10.1038 /nature 07333

Escartín J, Mével C, Macleod CJ, McCaig AM (2003) Constraints on deformation conditions and the origin of oceanic detachments, the MidAtlantic Ridge core complex at $15^{\circ} 45^{\prime} \mathrm{N}$. Geochem Geophys Geosyst 4(8):1067. https://doi.org/10.1029/2002GC000472

Escartín J, Mével C, Petersen S, Bonnemains D, Cannat M, Andreani M, Augustin N, Bézos A, Chavagnac V, Choi Y, Godard M, Haaga K, Hamelin C, Ildefonse B, Jamieson J, John B, Leleu T, MacLeod CJ, Massot-Campos M, Nomikou P, Olive JA, Paquet M, Rommevaux C, Rothenbeck M, Steinführer A, Tominaga M, Triebe L, Campos R, Gracias N, Garcia R (2017) Tectonic structure, evolution, and the nature of oceanic core complexes and their detachment fault zones $\left(13^{\circ} 20^{\prime} \mathrm{N}\right.$ and $13^{\circ} 30^{\prime} \mathrm{N}$, Mid Atlantic Ridge). Geochem Geophys Geosyst 15:3532-3543. https://doi.org/10.1002/2016GC006775

Expedition 340T Scientists (2012) Atlantis Massif Oceanic Core Complex: velocity, porosity, and impedance contrasts within the domal core of Atlantis Massif: faults and hydration of lithosphere during core complex evolution. IODP Preliminary Report 340T. https://doi.org /10.2204/iodp.pr.340T.2012

Früh-Green GL, Orcutt BN, Green SL, Cotterill C, Expedition 357 Scientists (2016) Atlantis Massif Serpentinization and Life. In: Proceedings of the international ocean discovery program 357, College Station, TX (International Ocean Discovery Program), http://dx.doi.org /10.14379/iodp.proc.357.2017 
Harding AJ, Arnulf AF, Blackman DK (2016) Velocity structure near IODP Hole U1309D, Atlantis Massif, from waveform inversin of streamer data and borehole measurements. Geochem Geophys Geosys. https://doi.org/10.1002/2016gc006312

Henig AS, Blackman DK, Harding AJ, Canales JP, Kent GM (2012) Downward continued multichannel seismic refraction analysis of Atlantis Massif oceanic core Ridge. Geochem Geophys Geosys. https://doi.org/10.1029/2012gc004059

Hosford A, Tivey M, Matsumoto T, Dick H, Schouten H, Kinoshita H (2003) Crustal magnetization and accretion at the Southwest Indian Ridge near the Atlantis II fracture zone, 0-25 Ma. J Geophys Res. https://doi.org/10.1029/2001JB000604

Ildefonse B, Blackman DK, John BE, Ohara Y, Miller DJ, MacLeod CJ, IODP Expeditions 304/305 Science Party (2007) Oceanic core complexes and crustal accretion at slow-spreading ridges. Geology 35:623-626. https://doi.org/10.1130/G23531A.1

Iturrino GJ, Ildefonse B, Boitnott G (2002) Velocity structure of the lower oceanic crust: results from Hole 735B, Atlantis II Fracture Zone. In: Natland JH, Dick HJB, Miller DJ, Von Herzen RP (Eds.), Proceedings of the ODP scientific results, vol 176, pp 1-71, College Station, TX (Ocean Drilling Program), https://doi.org/10.2973 /odp.proc.sr.176.018.2002)os601

John BE, Cheadle MJ (2010) Deformation and alteration associated with oceanic and continental detachment systems: Are they similar? In: Rona PA et al (eds) Diversity of hydrothermal systems on slow spreading ocean ridges, vol 188. AGU Monograph. Wiley, Hoboken, pp 175-206

Karson JA, Früh-Green GL, Kelley DS, Williams EA, Yoerger DR, 
Jakuba M (2006) Detachment shear zone of the Atlantis Massif core complex, Mid-Atlantic Ridge, $30^{\circ} \mathrm{N}$. Geochem Geophys Geosyst. https://doi.org/10.1029/2005GC001109

MacLeod CJ, Searle RC, Murton BJ, Casey JF, Mallows C, Unsworth SC, Achenbach KL, Harris M (2009) Life cycle of oceanic core complexes. Earth Planet Sci Lett 287:333-344. https://doi.org/10.1016 /j.eps1.2009.08.016

MacLeod CJ, Dick HJB, Blum P, Expedition 360 Scientists (2017) Southwest Indian Ridge Lower Crust and Moho. In: Proceedings of the international ocean discovery program, 360: College Station, TX (International Ocean Discovery Program) http://dx.doi.org/10.14379 /iodp.proc.360.2017

Michibayashi K, Hirose T, Nozaka T, Harigane Y, Escartín J, Delius H, Linek M, Ohara Y (2008) Hydration due to high-T brittle failure within in situ oceanic crust, $30^{\circ} \mathrm{N}$ Mid-Atlantic Ridge. Earth Planet Sci Lett 275:348-354. https://doi.org/10.1016/j.eps1.2008.08.033

Minshull TA, White RS, Mutter JC, Buhl P, Detrick RS, Williams CA, Morris E (1991) Crustal structure at the Blake Spur fracture zone from expanding spread profiles. J Geophys Res 96:9955-9984

Morris E, Detrick RS, Minshull TA, Mutter JC, White RS, Su W, Buhl $P$ (1993) Seismic structure of oceanic crust in the western north Atlantic. J Geophys Res 98:13879-13903

Pettigrew TL, Casey JF, Miller DJ et al (1999) In: Proceedings of the ODP initial reports, 179: College Station, TX (Ocean Drilling Program). https://doi.org/10.2973/odp.proc.ir.179.1999

Purdy GM, Detrick RS (1986) Crustal structure of the mid-atlantic ridge at $23^{\circ} \mathrm{N}$ from seismic refraction studies. J Geophys Res 
$91: 3739-3762$

Robinson PT, von Herzen R et al (1989) In: Proceedings of the ODP Initial Reports. 118, College Stations, TX (Ocean Drilling Program), https://doi.org/10.2973/odp.proc.ir.118.1989

Schroeder T, John BE (2004) Strain localization on an oceanic detachment fault system, Atlantis Massif, $30^{\circ} \mathrm{N}$, Mid-Atlantic Ridge. Geochem Geophys Geosys. https://doi.org/10.1029/2004GC000728

Tucholke BE, Lin J, Kleinrock MC (1998) Megamullions and mullion structure defining oceanic metamorphic core complexes on the MidAtlantic ridge. J Geophys Res 103:9857-9866

Xu M, Canales J-P, Zhao X, Yan W (2017) Seismic imaging of the Kane oceanic core complex using early-arrival full waveform inversion and pre-stack depth migration of multichannel seismic streamer data, AGU Fall Meeting, Abstract T32C-07

Zervas CE, Sempere J-C, Lin J (1995) Morphology and crustal structure of a small transform fault along the Mid-Atlantic Ridge: the Atlantis fracture zone. Mar Geophys Res 17:275-300 